1968

\title{
The WAIS as a Group Test of Intelligence
}

Robert Francis Eme

Loyola University Chicago

Follow this and additional works at: https://ecommons.luc.edu/luc_theses

Part of the Psychology Commons

\section{Recommended Citation}

Eme, Robert Francis, "The WAIS as a Group Test of Intelligence" (1968). Master's Theses. 2286.

https://ecommons.luc.edu/luc_theses/2286

This Thesis is brought to you for free and open access by the Theses and Dissertations at Loyola eCommons. It has been accepted for inclusion in Master's Theses by an authorized administrator of Loyola eCommons. For more information, please contact ecommons@luc.edu. (c) (i) $\Theta \Theta$

This work is licensed under a Creative Commons Attribution-Noncommercial-No Derivative Works 3.0 License. Copyright (C) 1968 Robert Francis Eme 


\section{THE WAIS AS A GROUP TEST OF INTEITIGENCE}

$$
\text { by }
$$

Robert Francis Ene

A Thesis Submittod to the Faculty of the Graduate Sohool of Loyola Univorsity in Partial Fulfilimont

of the Requiroments for the Degree of

Mastor of Arts

June

1968 


\section{LIFE}

Robort Francis Emo was born June 24, 1943, in Chicago, Illinols. Ho Eraduated from Quigley High School, Chieago, IIInols in Jun 1965, and reoelved the Bachelor of Arts in Philosophy from St. Mary of the Lake Seminary, Chleago, IIIInois, in June 1965.

After boing a spocial student in the Eraduate school at Loyola Univeraity for one year, the author entered the graduate program in Clinical Psychology at Loyola University in Septombor 1966. Ho has sorved as an assistant to Dr. Robort C. Nicolay for one year. In October 1967 he began his clerkship at the Loyola University Guldance Center and is prosentiy working in that capacitJ. 


\section{ACKNOWLEDGMENTS}

The author is primar1ig Indebtod and espocialiy grateful to Dr. Ronald E. Walker for his Interest in, support and oncouragemont of not only this rosearch, but also his caroor as a graduate student. Gratitude is expressed to the introductors psychology instruetors and students, without whom this research would not have boen possible. 


\section{TADLE OF CONTERTS}

Chapter

Pare

1. INYRODUCTION AND SURVEY OF IITERATORE

11. METHOD

111. RESULTS

2V. DISCUSSION OF RESULRS

V. SUMMARY
1

14

18

45

48 
Introduction and Survey of Literature

The revision of the Weschler-Bellovue Scales which took place In 1955 resultod in the current edition of the Woschler Adult Intolligene scale (WAIS). The excellenco of this rovision can bo soon from the ract that only a fow short yoars after it had been on the market Guertin (1959) could say "For the tirse being at loagt, the WAIS stands alone with very little competition. It can bo expocted to take its place a a paragon of intelifgence tosta. And as of this writing, it sooms that the WAIS Indoed has achiovod a status as paragon of intelligeneo tests as Guortin expectod. This is indioated by the amount of resoarch interest in the scales (577 artioles in Wosohlor's book (1958), the fact that it has boen translated into sovoral difforent languagos and now is usod in many difforent countries throughout tho world, and the fact that It is the instrument in clinical situations when an intelloctual oraluation is noedod.

The rason for this succoss is not hard to iscover; for one has but to consult the reviowers in Buros to find out that it is because of the tost's excellent construetion and the representativeness of $1 t_{8}$ norms that it has won the favor of the clinieian. Despito the fact that the WAIS was initially dosigned as a clinfcal instrument and has made its reputation in this area, this has boon by no means the only way in which it has boen used. In ract if one may judge from the 197 articles contained in Guretin's (1966) reviow, the WAIS is bocoming almost as popular as a 
researeh instrument as it is as a clinfeal instrument. Hence for the same roasons as given above, Guertin roports that "work with Woschlor's scalos goos on unabated." And this researoh in which the WAIS is involved sooms to be as diverse as the research Interests of the paychologist himsolf, as indicated by the followlag studios.

The WAIS has been used to Investigate intelligence as a function of age in soveral longltudinal and oross-seotional studies. Bradway and Thompson (1962) Inrestigated the montal Erowth rate of normals, Bell and Zabok (1960) tho montal growth rate of defectives, and Elsdorfer (1963) the doterioration of the I.Q. of $\mathrm{SB}$ botwoen the ages of 60 and 70 . Hullaka (1962) omployed the WAIS in a cross-sectional design on Ss with mean age of 69 in relating change in I.Q. to ability lovel.

The WAIS has boen used in the study of mental dofoctives. S1Iverstein (1962) studies the correlation between the WAIS and length of hospitalization. Tarjan ot al. (1960) found the reloase rate of male and fomalo mental defoctives to be funotion of rull seale I.Q.

The WAIS has been used in the study of $98^{\circ}$ function. For oxamplo, Devereaux Foundation has used the WaIS in its continued studies of I.Q. and ogo dolay functions. Portinent to this rosearch are the studles roviewed by Levine, Splvak, and Wright (1959) In which the Rorschach M was correlated with WAIS I.Q. scores.

Psychothorapy research has made use of the WAIS as indicatod 
In atudy by Hanover (1965) in which a correlation was found botween $I . Q$, and success or duration in therapy.

Researchers have used the WAIS In rany studes rolating numerous varlables to the performance of sehizophronios. IIIustrative of the rosoarch in this area 18 a study by De Luos (2964) In which he rolated an oxaminer ostablishod "sot to improvo" wh poor premorbid performance on the WAIS. Ho found that they improved or doclinod as a function of tho set, regardless of the Intorvening positive or nogative evaluation.

Finally G1lgash (1961) used the WAIs to atudy the effects of thorazine on the I.Q. catatonic schizophronica.

In all the above rosearch studios the WAIS was used as an Individual test, but tho possiblity exists for its use as a group tost. This lea auggest itsolf from the fact that the WaIS 1tsolf has been frequently used as a criterion of validity for many of the most widely used group tests of Intelligonce as the following roview indioates.

Wions and Banaka (1960) conductod a study to Invostigato tho comparability of the Shiploy-Hartford (S-H) acores and the WAIS rull scale I.Q. They concluded that the S-H an be proritably usod in hospltal sottings as a subatitute for tho WaIs whoro -conomy of adrinistration is desired.

Sulnn (1960) and wahler and watson (1962) have both conducted studies the purpose of which was to investigate the validity of the S-H as acroening dovice, since offelont work in institutions with large patient populations roquires the avaliability of 
tosts which can be briefly administorod and intorproted. Corrolation with the WAIS was taken as the moasure of the S-H's validity for this function. Thosi conclugions wore that when I.Q. is a minor variable in a doclsion corplox and only a broad catogorization Is required for the ofrcumstances, the findings support the position that the S-H can be sueficiont.

Stone and Ramer (1965) state that although the S-H appoars to be valuable as an economioal substitute for the waIs when only an I.Q. ostimate is required, the rason for their study was to investigate the rolationship botweon the $3-\mathrm{H}$ asd the waIs under more typical clinteal conditions than the novo studios. Tholr study involvod using aAS I.Q. based on 6 or moro subtests rather then requiring administration of all eloven, and the adrinistration of $\mathrm{S}-\mathrm{H}$ and WAIS tests by 10 difforent paychologiats. They roported a correlation of .79 botween the S-H and severeI WAIs subtests and hence confirmed the flndengs of provious studios.

Darbes (1960) conductod a sudy in whioh the WAIS was used as 2 criterion measure for the Otis. He roports correlations ranging from .75 to .87 for the two tests.

Warron and Collier (1960) were interestod In the use of the Columbla Montal Maturlty Scalo as a screoning dovioe for retarm dates, using WAIS scores as the orfterlon for roturdation. They report correlations ranging from .68 to .70 botwon the two tosts. Jurjovich (1963) statos that psychologists working in inst1tutions are often faced with the problems of classifleation and 
-valuation of intellectual capsolit for porsons in groups too lare for Individual ovaluation. Group tosts are often bolag used for large numbers of lnstitutionelized subjects; and this prosedure 1 s often acoompaniod by considerable discomfort to the psjoholegist who has to resommen some impertant doeision on the basis of 1nstrument suspocted to have a low validity for the group in question. Hia study representer an attompt to invostigate the applicability of the Henmon-Helson to spectrie kind of institutionalized subjoot, the delinquent girl. The sultablity of the Hemmon-Nolson as a group test of lnteligence for this Inatitutionalized group ras gontalned by establishing ita conourrent validity with the WAIs. The auther roports correlatione ranglng from .69 to .83 for the tro tests.

The Ravens Progrengtve Matrieeg Tost has alao used eorrelation with the WAIS as aritorion of 1 ts validity. MoLood and Rabia (1962) report that oorrelation with the WAIs range from .58 to .67 - wth a group of nouretios. Orne (1861) conducted a study uslag the celored Raven's and found correlations ranglat from .75 to .98 with retarded Eroup.

With respect to the Gallfornia Test of Montal Haturitles, the manual eltos five eritorie of 1ts validity. One of the criterla empleyed is oerrelations with other intelifgenee test including the WAIS. Freamen (1859) reporte that on the whole coefficionts reaulting from these velidating atudies, which were carried out by Investigators other then the authors of the teat, aro antafactory or eren high, ospeelally in the cage of the WAIS. 
In his roview of the literature on the WAIS, Guertin (1866) sums up the situation by saying that the fact that the waIs is so frequently ues as oriterion mosure for group tests of intell1gence tostirlos to the valletty generaliJ assumed to characterizo 1t. The 1den of using the waIS 1tself as group togt of Inteli1gonoe, would senm to be especially valuablo for several reasone. Firat, 1t would sem obvious from the above review that a group wAIs would be a more valle and rollable test than the above tests ino it is the standard itself which is boing emploged rather than the tosts which are based on the standard, and since, as Jurjevich (1963) we well observed, meng of the tests now omplojed are of anapeot validity.

Second 1t beems that the norms of the WAIs are auperier to those of the other tests, and honce persen! scoro could be more moaningfulis intorpreted. support for this reason oces from tho varlous reviewers of the above teats.

Conoerning the neras for the WaIs, Guertin (2966) in his wovlow aucelnctiy aume up hio evaluetion of tholr adequacy by repert ing thet "...one ls onecuraged to ecoept these now norme quite unconditionelly for a elinioal pepulation." Hence it appoars that a good don of confldenoe can be placed in the representiveness of the WAIs's norms. However the plcture is rar lose senguine for many of the other widely uaed group intelilgonce toats, es the following reviewers report.

In oraluating the norms for the Shiplej-Bartford, Ires (1948) reporte that alnoe the stenderdization 18 on 1046 individuals, all 
students fron the 4 th grade up thru collego, one finds that the tost sots norms which aro highor than an unselected sample as found in the hospltals whers the $s-H$ is used.

Sho gos on to state that boosuse the s-H 1 s net conaldered valle for those with shipley voombulary age below 14 jeara. this sxcludes not only feobleninded and borderilne individuals. but the entir. lower half of the pepulation as meacured by the Binet or Bellevuo. Also the standardiation group includes no eler poople and therefore no allowane is ande for nomal retroGrosion, which 1. important in eny pationt population.

In reviewing the Ot1s Group Intelilgence neale, Leferer (1965 gtates that a comparison betweon the 1020 and 1938 norms shoved that the original norms were too low by more than 50 per cent at the 6 and 7 jear ago lovelo. The difference between the 1920 and 2838 norme diming shes to 208 s than 2 per oent at the 12 year age level. And he geos on to say in view of this ahift between 1980 and 1938 norms and ince the 1938 norns are the latest roported, one wonerer whether any aditional ahift in norm values would be shom if more recent survejs were conduoted. In short, he states that by today's standarda the Information furnl shad by the coneumor of the 0tis se both antiquated and inadequete.

In his revisw of the Columbia Mental Maturity scale, Hiajey (1965) states the progent rovision of the original soale (1954) took place aftor roports of regearch gave highly conflioting ovidenoe as regard to validity and rellablitty oopflelents, adequacy of norms, Itom diffioulty, and the rationalo for response, 
However as Herland (1965) pointed out there is an abseneo of any drect ovidonce for the reliablilty of the revialon; and hence one wonders to what extent the revialon has corrected the above eriticism.

Concerning the norms per so, the reader is advised in the manual itseif that tho procedures utlized to atandardize the tost w112 tend to perpetuate, in the Columbla's norm, any syeteratie errors present in the nowms for the other tests. The reason for this acvisenent is that the publishers forthrightig admit that they asumed the comparablilty of the group tests used in the standardzation and honce there ls the resulting possiblitty of the Columbia's norms reflecting or perpetuating any ayatematio eprors present in the nows of these croup tasts. Wewland (2803) also ade the caution that the critseal user of this tost will be aware of the posibility that the East Coast nomb of the Columbia may not be senerelis applicable.

In short H18key (1965) state that the norws used to interm prot the performance on the Columbla should be ut1I1zed rith caution, expelails at the oxtremes.

Concorning the Hennen-NeIson at the college lovel; $1.0 .$, at the level in wheh it is comparable to group intalizgence tost for adults, Crites (1965) reports that the nature of the nat1onal pormative data rostricts the applicability of the test to ooliege feoshmen. However at the lower level grades 3-12 reviewers sueh as Lefever (1959), Tyler (1959), and Shaffer (1959) are unanimous in theip pratis of the noms. 


\section{$-5-$}

The adequacy of tho norms for the Ravens P-M Is concisely summed up by Cronbach (1960) when he reperts that the inablilty to comparo caso with an accoptablo American norm is serious drawback to the use of the tost.

As rogards the California Tost for Mental Maturity, Frooman (1959) roports that the standardization population appoars to be quito satisfactory as to numbors, goographlcal distribution, and stratification. Hence this is the only test of those reviewed which usod tho WAIS a a criterion measure and had satisfactory norms.

Concerning the other Important group tosts of intelligenco which do not use the WAIS as a criterion measure, the reviewers have the following comments on their standardization.

Anastas 1 (1961) makes the following eritical ovaluation of the norms for the Primary Montal Ab111ties Tost. She reports that the normative samples, wh1lo generally satisfactory as to sizo, are Inadequately described with reference to soclo-economic level, goographical distribution, proportion of urban and rural subjocts, hational and othnic origin, and other relevant charactoristics. It seoms IIkeIJ, she says, that the samples omployed are quite pestricted and unropresontative of the country at largo in one or more of these categories. More information rogarding these nomat1ve samplos is noeded in order to determine just what population is samplod. Yot the norms are offored for general use without qualification. Another shortcoming whloh she roports is the lack of separate sex norms or any discussion of sex differoneos. 
Concerning the Kuhlman-Anderson, PIdgeon (I965) reports that unlike achlovement tosts, nationally representative norms aro of paramount importance for Intelifigonce tests. He goes on to say that though this certainly appears to be the viow held by the test authors, the stops taken to insure reprosentative sample fall short of 1doal.

Hoyt (2959) reviened the Ohlo State Psychological Examination which runs from grade 9 thru colloge. At the colloge lovel, the level which would be comparable to group test of Intelligence for adults, he reports that the norms are tentative.

As regards the Differential Aptitude Battery (DAT), Keata (1965) roports that an overall standardzation samplo of more than 50,000 seems vory substantial indeod, but whon it is dividod by grade, sex, and time for testing, it is found that each set of norms $1 \mathrm{~s}$ based on littlo more than 2000 cases. He adds that oven these amples are quite adequate and probably larger than those used by most agencies.

Thus it is apparent that with the excoption of tho California Test of Mental Maturities and the Difforential Aptitude Battery, the adequacy of the norms for the most widely used group tests of intelligenco is such that one must ontertain serious reservations about the meaningfulness with which a person's scoro on these tests can be interpretod. In addition to the above aentioned reasons for the value of group waIs there is in addition the fact thet the norms for a group WaIS would be superior oven to tosts such as the California Test of Mental Maturitios and the 


\section{II-}

Difforont1al Aptitude Battery since its norns are adequate upward to age 70 while those of the CTMM and the DAT atop at age 17 ; and it is only by the dublous prooss of extrapolation that they aro oxtended boyond that lovel.

Also with the excoption of factor analytic battories such as the DAT and the PUA group tost of Intelligence do not give a pleture of the rarlous aspects a group WAIS would give of I.Q. In this respect it would soem to be auperior to the other group tosts which do not purport to slihouette the various facets of I.Q.

Finally, as the above-reviowed studies of wions and Banaka (1960), Sulnn (1960), Wahler and Watson (1962), Stone and Ramer (1965), Warron and Coll1er (1960), and Jurjovich (1963) Indioated. there is a real ollnioal noed for a test whioh oan bo usod as a scroening dovice. Since a group WAIS to be proposed in this thesis could bo administered in a far shorter time (approximately a half hour) than most existing group testa of intelligonce. It would sosn to admirably fulfill this nesd.

Hence it would seom that for the above ressons, a group WAIs would not be meraly superfluous addition to an array of already oxisting group tosta of goneral intelligence, but would constitute valuable psjohological instrument. For it would onablo the paychologlat to arrive at a more valid and more moningful appraisal of Intelifgence, in a wuch shorter time and for a much broader population then he 1 s preantly able to with oxisting group tests of Intelligenee. 
Once having shown the value of a group WAIS its feasibility Is domonstrated by studies such as those of Doppelt (1956) and Maxwell (1957) whoroby a judiolous solsction of subtests were shown to yield an extremely high oorrelation with the full seale I.Q., to tho oxtent that the correlations were noarly oquivalont to the WAIS's test-retest reliabilitj. Thus a valid, rellablo I.Q. can be obtalned in onlJ a fraction of the usuel time through the administration of only a for of the subtests. Also, because the correlations betwoen the subtests are known, what an individual would have scored on the other subtests oan be easily obtaine; and therefore, desplts the brevity of the tost, a plcture of the varlous aspects of a person's I.Q. comparable to that fiven by the full soale WaIs can also bo attained. And finally the foasibility of adapting an individual I.Q. test for Eroup aiministration has boen denonstrated in a study by Fargo. Crowell, Nojos, Fuchigami, Gordon, and Dum-Rankin (1967). Thes study was condusted to axaine the feasibility of adapting the Poabody PIcture Vocabulary Tost for Group administration by moans of educational telovision. Tho mesults lndicated that the scores of Individual and Group adrintstration ware comparablo and honce that the Poabody thru aconomioal group administration could be used as a screening dovice.

In short, it sooms ontiraly foasible that by means of a group WAIS a valid rollable eatimate of an Individual's I.Q. could be arrived at in half of the usual testing time without sacrifleing any of the deferential aspects of I.Q. assumed to bo 
$-13-$

gotten thru a full scale administration of the WAIS.

Thus this study is conducted with the purpose of examining the possibility of adapting the WAIS for group administration. The objective is to test the hypothesis that scores obtained in group administration would not signiflesntiy differ from those obtained In Individual administration. The Investigator believes that if the two administrations are found comparable, the oconomica group administration o ul servo as valuable substitute for Intelligence test which are not being employed in many clinical situations; and its implleations as screening device for both clinical and non-clinical situations ae manifold. 


\section{Prooedure}

Subjoots

The Sg employod rore 100 undergraduate oolloge students who wore dram from three dfforent ollegos located in Chloago. IIIInols; numbly, Rosary, st. Mary of the Lake, and Loyola. AIl 100 rooalvod the group tost in sroups ranglng in size from 5 to 30. while 60 (30 malo, 30 fonalo) took the Individunl tost in addition to the group tost. AII tho subjocts involved wore rolunteers who wore asked to participate in en experiment in ordor to holp graduato atudent in psychology gather data for his Hastor's thesis. They wore told that the experiment would linvalve taking subtests from an I.Q. tost and would require about 1 hour of thatr time.

subjects from Lojola were gotton in two rays. An appond wa mado for volunteors in two aumor chool poyohology ooursos at Lojola and also one of Loyola's asereterios onlistad the paptielpation of her frionds, all of who wore part-tleo oellege undergraduatos.

Subjocts from Rosary and St. Mary of the Lake were gotten thru the $1 d$ of E's Frionds who contacted follow tudents and askod them to volunteor.

\section{Apparatue}

The material emplojed for the group adminietration of the WaIs were the aubtests of Information (I), similarities (S), Ploture Completion (PC), and DIgit symbel (DS). Theae wore choaen 
because of thotr aultablitty for group administration and bocause of thelr high correlation with the full scalo I.Q. as indicatod by Maxre11 (1957).

Individual answer sheets wore provided for the $\mathrm{Sg}$. Tho answor shoets for $I, S$, and $P C$ consisted in a singlo shest for each subtest in which tho number of oach quostion was listed followed by apace for answaring. The anawer shetis wore titlod, MEST I, TEST II, TEST III, rospeotively. The auswor aheot for DS wrs titied IV and consigted of a mimeographed copy of the test itgelf. The reason for using individual answer shets whioh were so titled instea of simply using Woschler forms was to adhoro to the toet standardization olosoly as possible. Sinoe in an Individual administration the tosteo doss not omploy the woschlor form nor does he know the title of the aubtest which he is taking. 1t was felt that those samo condition should prevall in a froup administration.

An overhead profector and screen wore used whereby the examples called for in the instructions on tho DS woro 1llustrated and also whereby the plcturas of the PC wore projoctod for viowing.

For the individual miniatration the subtost of Vocabulary, Ar1thmet1c, Blook Desfgn, and Pleture Arrangoment wore omployed bocause of their high correlation with the full soalo I.Q. a shown by Maxrell (1957).

Pour subtests, two varbal and two porfomance were omployed in each condition for as Mexwoll demonstratad, tho acouracy of 
the aboreviated seales is a function of the number of abtests Inoluded and that while verbal scalos are generally bottor prem doters than performanc scales, a comblnation of both verbal und porformance subtests is best.

Digit Span and Objoot Aasomid were eliminated from tho tost battery boease, as the Weschler manual ladioates, their corrolations with the full scale I.Q. are the lowest of all the subtsits. Comprohongion was not IHeluded for two reasons. First, factor anelytic studies suct as the one by cohon (1956) have desonatrated that the factorlal conposition of Comprehension doen't include anything ilfferent from that of Information or Vocabulary. Hence it would soen that tho lmportance of 1 ts Inolusion in the tost battory would be minimal. Second, studios suoh as those by Halker (1965) have shom that his ecoring of Comprohension items containa high dogroo of affrloulty and unellablity. Hence it would appear that the scoring of the subteats of Vocabulary and Information would be orsier. Thus the fact thet Comprohension aldn't soem to aed anything to the tost battory coupled with the diffoulty involved in its scoring militated against its inclusion in the present study.

\section{Procedure}

A counter-balanced treatment dealgn was ut111zod. Half of th S8. 15 male and 15 fomalo, had the individual prosentation prior to the group presentation and half had the group seselon firat. In the individual adminiatration, the sandardized procodure given by Wosohler was followod and they woro instructed not to 
tell the other Sa about the test.

In the group administration the following instructions were given.

My name is Robert Eme and I am a graduate student in paychology at Loyola presently working for my M. Today I would like to tuke about thirty minutes of your timo to gather somo data for work on my Master's Thesis. I am going to administor to you a group intelilgenco tost which is closely related to a widely used individual I.Q. test. The purpose of the administration is to relate group performance on the tost to individual performance on the tost. The first thing I would like to have you do is to sign your name at the top of the answer sheots. You w111 also not1co that your answer shoots are number Tost, $1,2,3,4$. During the tost I would ask you to rofrain from asking any questions or making any comments about tho tost and to pay close attention to the instructions. You aren't expeoted to know all the questions and those you don't know, skip and go on to the next number. The questions for the first tost are as follows: cf. Weschlor, Question one is ..............te.

The instructions used for oach of the four tests wore the same as those used in the individual administration oxeopt for the following rodifications. On the DS, the three examples called for in the instructions wore illustrated via projection on the movie screan rather than writing thom out for the individual, as is usually done. The Sa wore then instructed to complote the four remaining samplo questions themselves. On the PC after the third question was glven the following statement was made, by way of a rominder.

Remember to plck out the most significant thing missing.

Woschler states that such a rominder should bo given only 
once and oniy whon the $\underline{S}$ picks an unimportant missing part. Sine in the group situation it would bo impossible to know when an $\underline{S}$ plcks an unimportant part for the first time, it was folt that such a rominder was advisable in order to give the $\mathrm{Sa}$ in tho group test a situation more comparable to the one thoy would experience in the individual situation.

Total administration time took one half hour.

The stimuli for tests ono and two were read whllo those for three and four wore presented via the projector. On tests one and two, proceoding to the next item was based on two criterla. One was an interval of approximately 20 to 30 soconas, whioh was chosen on the basis of E's experience with the test. The second was observation by $E$ of the progress boing made by the Ss. 


\section{CIIAPTER III}

\section{Results}

Tables one to six contain the Pearson $\mathbf{r}$ correlations for the two administrations. These correlations have boen corrected for range restriction due to the homogenelty of the subjects omployed since they wore all college undergraduates. (of. McNomar, 1962.) The correlations in parentheses are those prior to the correction.

The moan and standard deviations of the intelligence test scores for the two adminlstrations aro contained in tablos sovon to twelve. These scores were calculated thru an extrapolation of the two vorbal and two porformanco subtests omployod in oach administration to the full soalo verbal and full seale performance I.Q.

The mean and standard doviation of the scaled scores of the individual subtests omployed in both admistrations aro containod in tablos thirtoon to olghteon.

Tablos nineteon an twonty contain the simplo Iinear regression predictions for the $60 \mathrm{sg}$ who recolved both administrations of the WAIS. The rogression for oach $\mathbf{S}$ was computed using the full scalo group I.Q. s the prodictor and the full soalo individual I.Q. as the criterion.

The rogression coefficients and the standare error of the estimate for the predictions are contained in table twenty-one.

Table twonty-two contains the ovaluation of the significance of the difference betweon the moan group $I . Q$. and mean individual 
$-26 \cdot$

I.Q. for males and females. The $t$ test for correlated moans was employed to evaluate the significance.

Table twonty-three contains the evaluation of the signifydance of the difference between the moan predicted $I, Q$. and the mean of the criterion of the I.Q. against which the prediction was made. Tho $t$ test for correlated moan was employed to evaluate the significance.

Table twonty-four contains the evaluation of the significantce of the difference between the varlablilty of group verbal performance and total I.Q. with thole counterparts in the individual administration. The t test for correlated variances was employed to evaluate the significance. 


\section{TABLE 1}

MEASURES FOR INTERCORRELATION OF I.Q. FOR 30 MALES

\begin{tabular}{|c|c|c|c|c|c|}
\hline & $\begin{array}{l}\text { Group } \\
\text { Vorbal }\end{array}$ & $\begin{array}{l}\text { Group } \\
\text { Porformance }\end{array}$ & $\begin{array}{l}\text { Group } \\
\text { Total }\end{array}$ & $\begin{array}{l}\text { Individual } \\
\text { Vorbal }\end{array}$ & $\begin{array}{l}\text { Individual } \\
\text { Porformance }\end{array}$ \\
\hline Group P. & $.32(.18) 2 \%$ & & & & \\
\hline Group T. & $.93(.80)$ \% & $.79(.77)$ & & & \\
\hline Individual $v$. & $.78(.56)$ 和致 & $.21(.11)$ & $.84(.40) * *$ & & \\
\hline Individual P. & $.32(.23)$ & $.14(.13)$ & $.66(.23)+2+3$ & $.83(.61)$ & \\
\hline Individual T. & $.53(.39)+4$ & $.15(.14)$ & $.80(.35) * *$ & $.99(.88) \times 2$ & $.91(.91) \div$ \\
\hline
\end{tabular}

- The correlations in parentheses are those prior to the corroction for range restriction. The significance values refer to the correlations correctod for range restriction. (cf. McNemar, 1959, p 241.)

$* p \quad .05$
$* p+.01$


TABLE 2

MEASURES FOR INTERCORRELATION OF I.Q. FOR 30 FEMALES

$\begin{array}{lllll}\text { Group } & \text { Group } & \text { Group } & \text { Individual } & \text { Individual } \\ \text { Verbal } & \text { Porformanco } & \text { Total } & \text { Vorbal } & \text { Porformance }\end{array}$

\begin{tabular}{|c|c|c|c|c|c|}
\hline Group P. & $-.11(-.08)$ & & & & \\
\hline Group T. & $.82(.75) \times$ & $.63(.55)$ & & & \\
\hline Individual $\mathrm{V}$. & $.88(.77) \div$ & $-.03(-.03)$ & $.94(.59) \div$ & & \\
\hline Individual P. & $.52(.38) * *$ & $.46(.35) * *$ & $.91(.51) H$ & $.31(.24) *$ & \\
\hline Individual $\mathrm{m}$. & $.86(.74) \div$ & $.22(.19)$ & $.96(.70)$ 背 & $.82(.73) * 4$ & $.82(.82)$ \\
\hline
\end{tabular}

$* p \quad 4.05$

p 4.01 
TABLE 3

MEASURES FOR INTERCORRELATION OF I.Q. FOR 30 MALES and 30 FEMALES

$\begin{array}{lllll}\text { Group } & \text { Group } & \text { Group } & \text { Individual } & \text { Individual } \\ \text { Vorbal } & \text { Porformance } & \text { Total } & \text { Vorbal } & \text { Porformanos }\end{array}$

Group P. $\quad .10(.05)$

Group T. $\quad .89(.78) * * 71(.67) * *$

Individual V. $.83(.65) * * 04(.04) \quad .89(.50) * 3$

Ind1v1dual P. .47(.31)* .30(.20)* $.79(.37) * 4 \% \quad .57(.42) * 4$

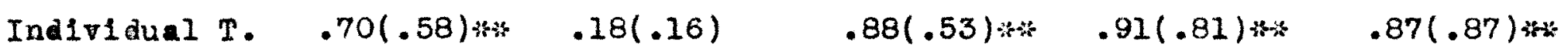

$* p<.05$
$* \quad p<.01$ 
$-24-$

TABLE 4

MEAS UREA FOR INTERCORRELATION OF I.Q. FOP 50 MALES

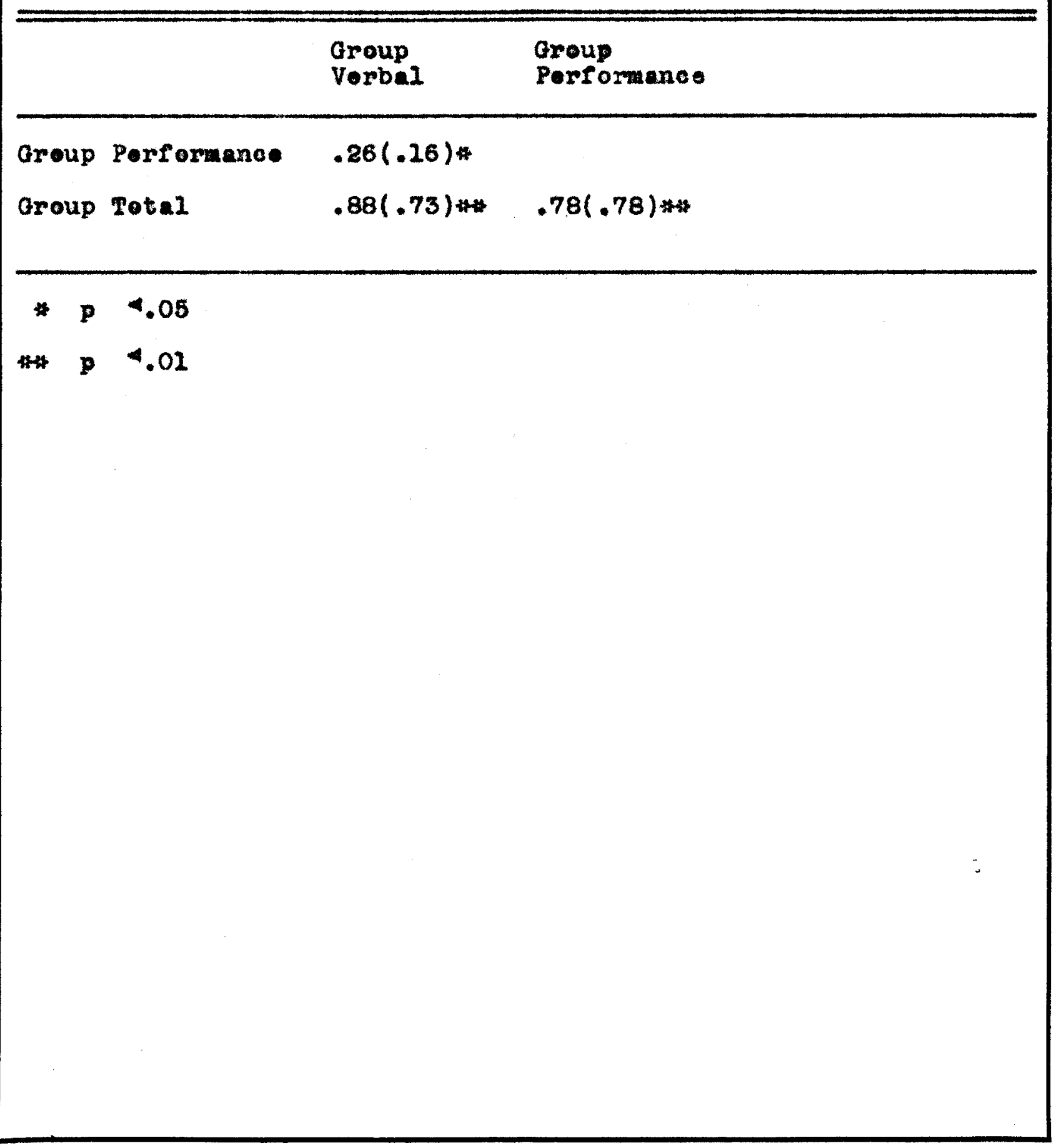


$-25-$

TABLE 5

MEASURES FOR IUTERCORREIJATION OF I.Q. FOr 50 FEMALES

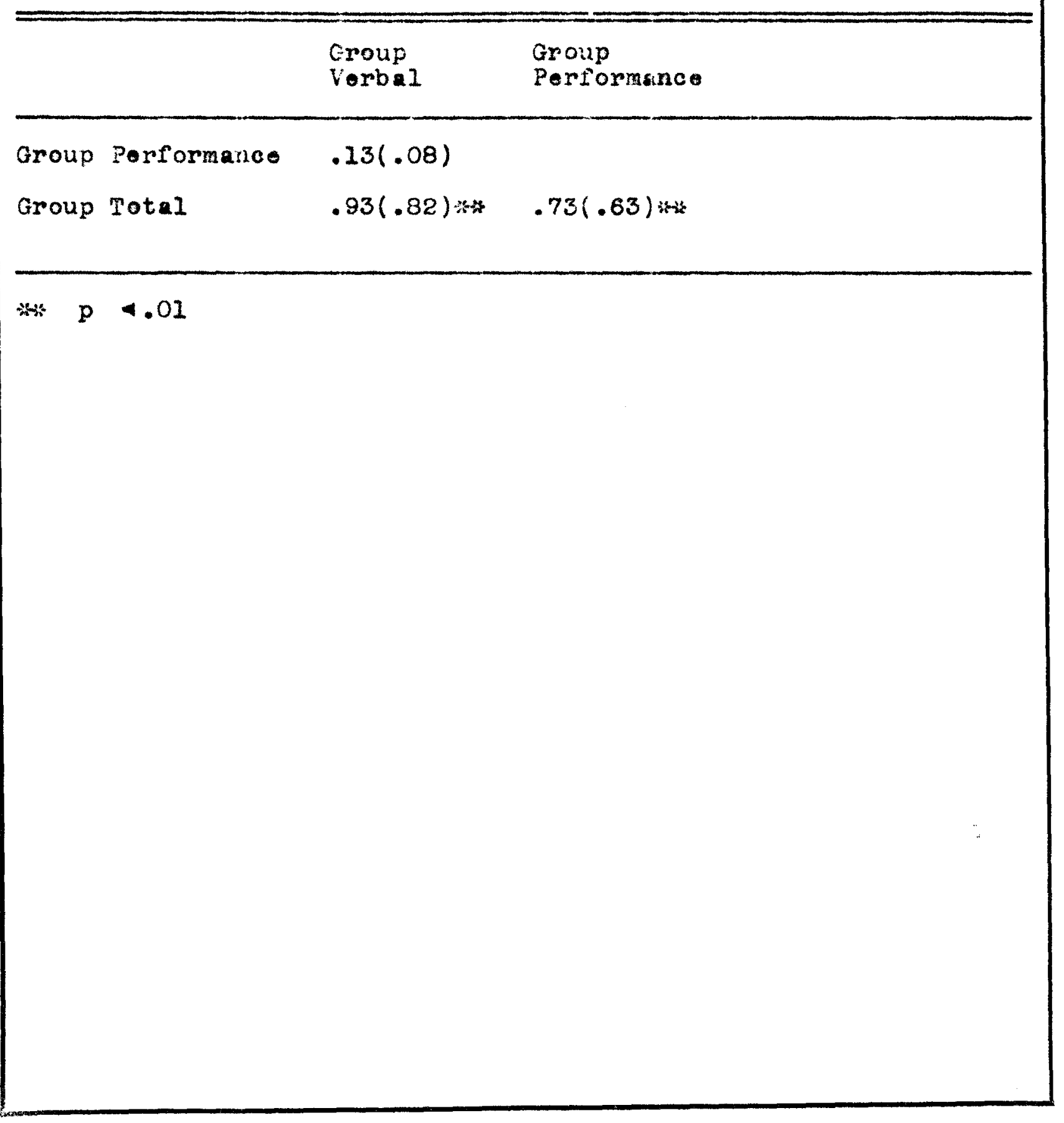


$-26-$

TABLE 6

MEASURES FOR INTERCORRELATION OF I.Q. FOr 50 MALES and 50 FEMALES

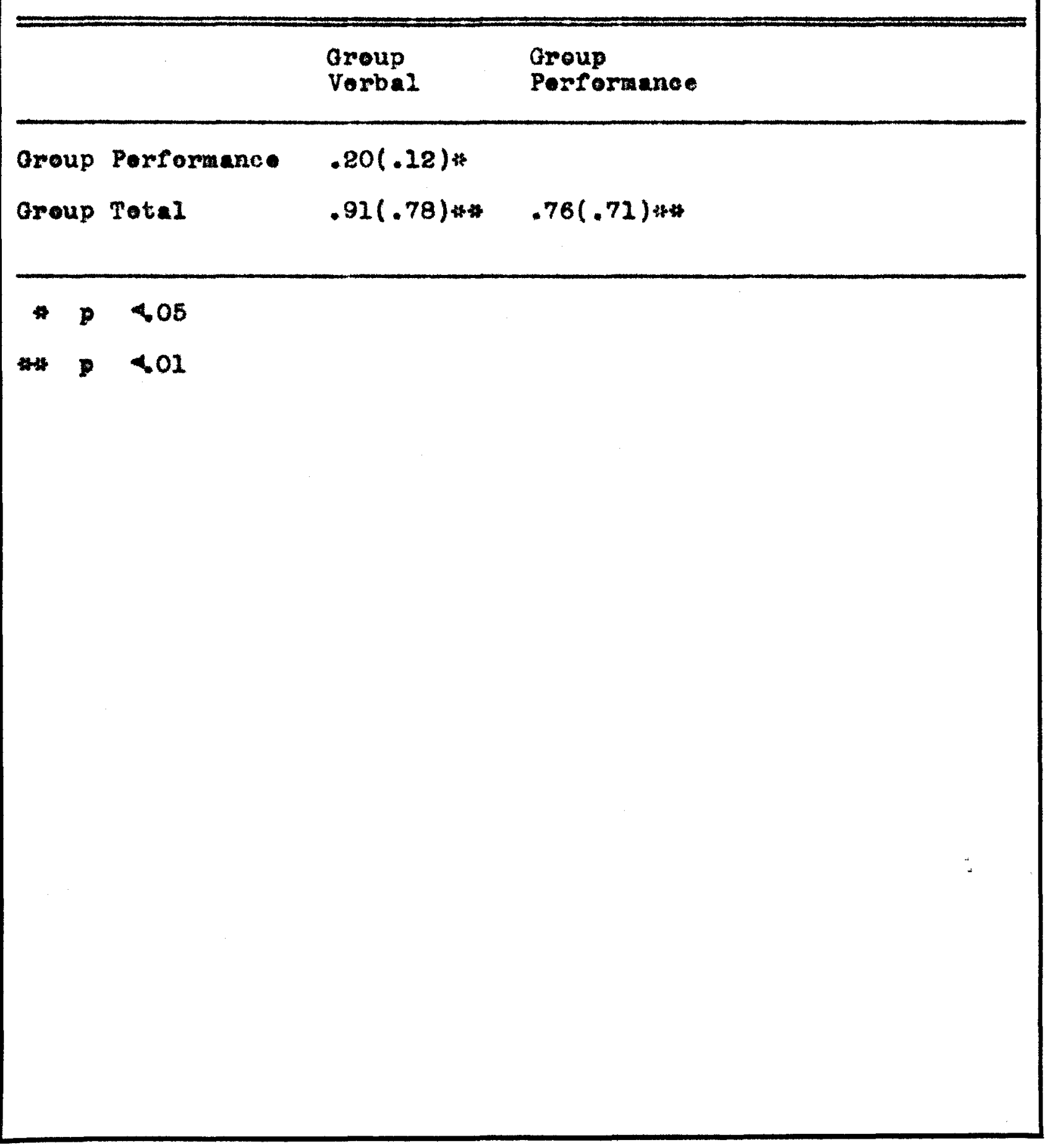




\section{PABLE 7}

MEAN AND STANDARD DEVIATION OF I.Q. SCORES for 30 MALES

\section{Meen Standerd Doviation}

$\begin{array}{lrr}\text { Group V. } & 121.93 & 8.33 \\ \text { Group P. } & 115.40 & 10.73 \\ \text { Group T. } & 120.03 & 7.50 \\ \text { Ind1 vidual V. } & 119.76 & 8.50 \\ \text { Individual P. } & 110.93 & 12.26 \\ \text { Ind1VIdual T. } & 117.00 & 9.73\end{array}$




\section{TABLE 8}

MEAN AND STANCARD DEVIATION OF I.Q. SCOFES for 30 FEMALES

Hean Standard Leviation

$\begin{array}{lrr}\text { Group V. } & 121.50 & 10.03 \\ \text { Group P. } & 116.46 & 9.93 \\ \text { Group T. } & 120.70 & 7.63 \\ \text { Individual V. } & 119.86 & 6.86 \\ \text { Individual P. } & 110.50 & 12.70 \\ \text { Individual T. } & 116.23 & 9.23\end{array}$




\section{TARLE 9}

MEAN AND STANDARD DEVIATION OF I.Q.SCORES for 30 MALES \& 30 FEMALES

Mean Standard Deviation

$\begin{array}{llr}\text { Group V. } & 121.71 & 9.13 \\ \text { Group P. } & 115.93 & 9.18 \\ \text { Group T. } & 120.50 & 7.56 \\ \text { Individus V. } & 119.51 & 8.73 \\ \text { Individual P. } & 110.71 & 12.48 \\ \text { Individual T. } & 116.61 & 9.48\end{array}$


$-30-$

TABLE 10

MEAN AND STANDARD DEVIATION OF I.Q.SCORES fOr 50 MALES

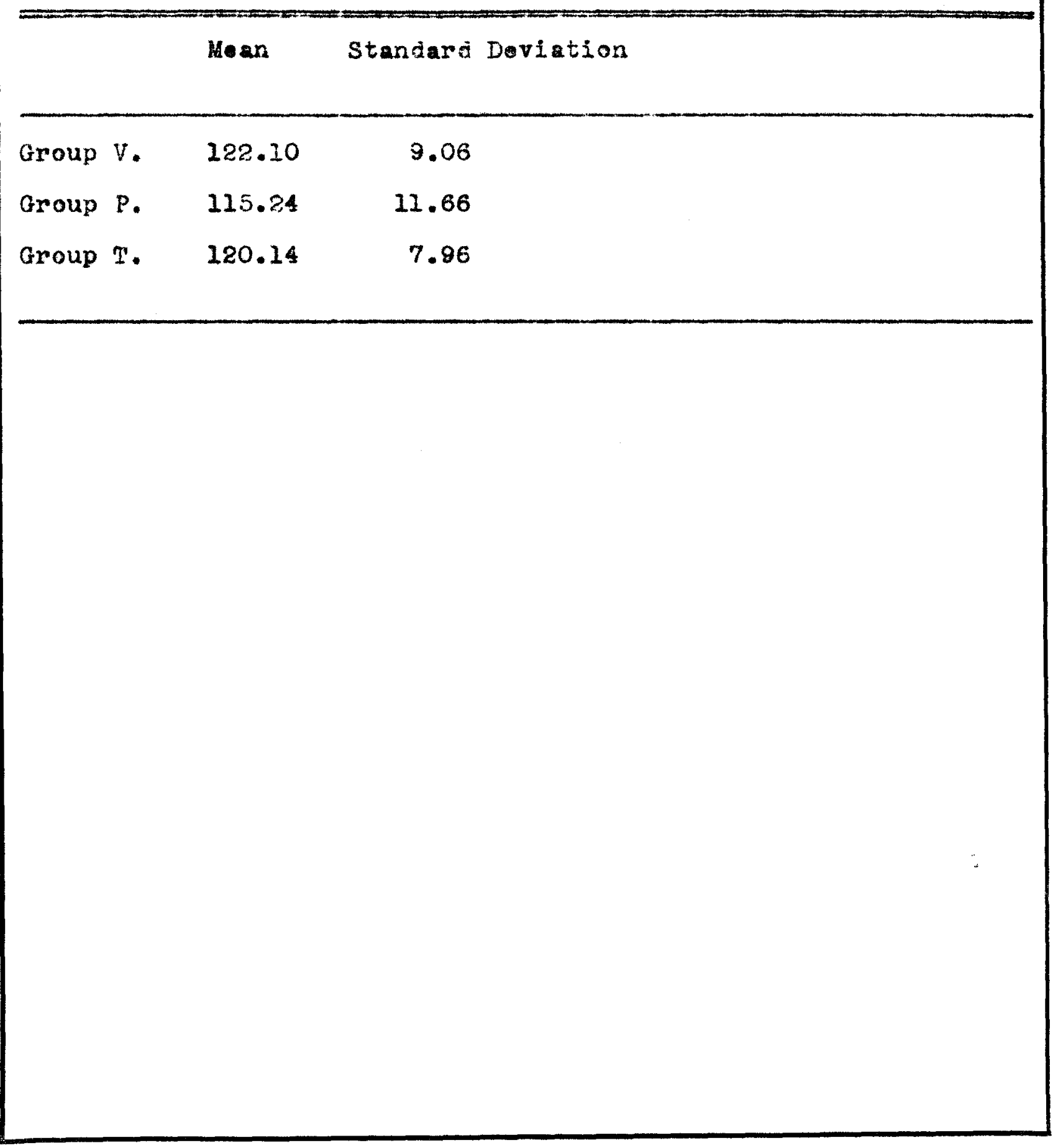


$-31-$

TABLE 11

MEAN AND STANDARD DEVIATION OF I.Q. SCORES for 50 FEMALES

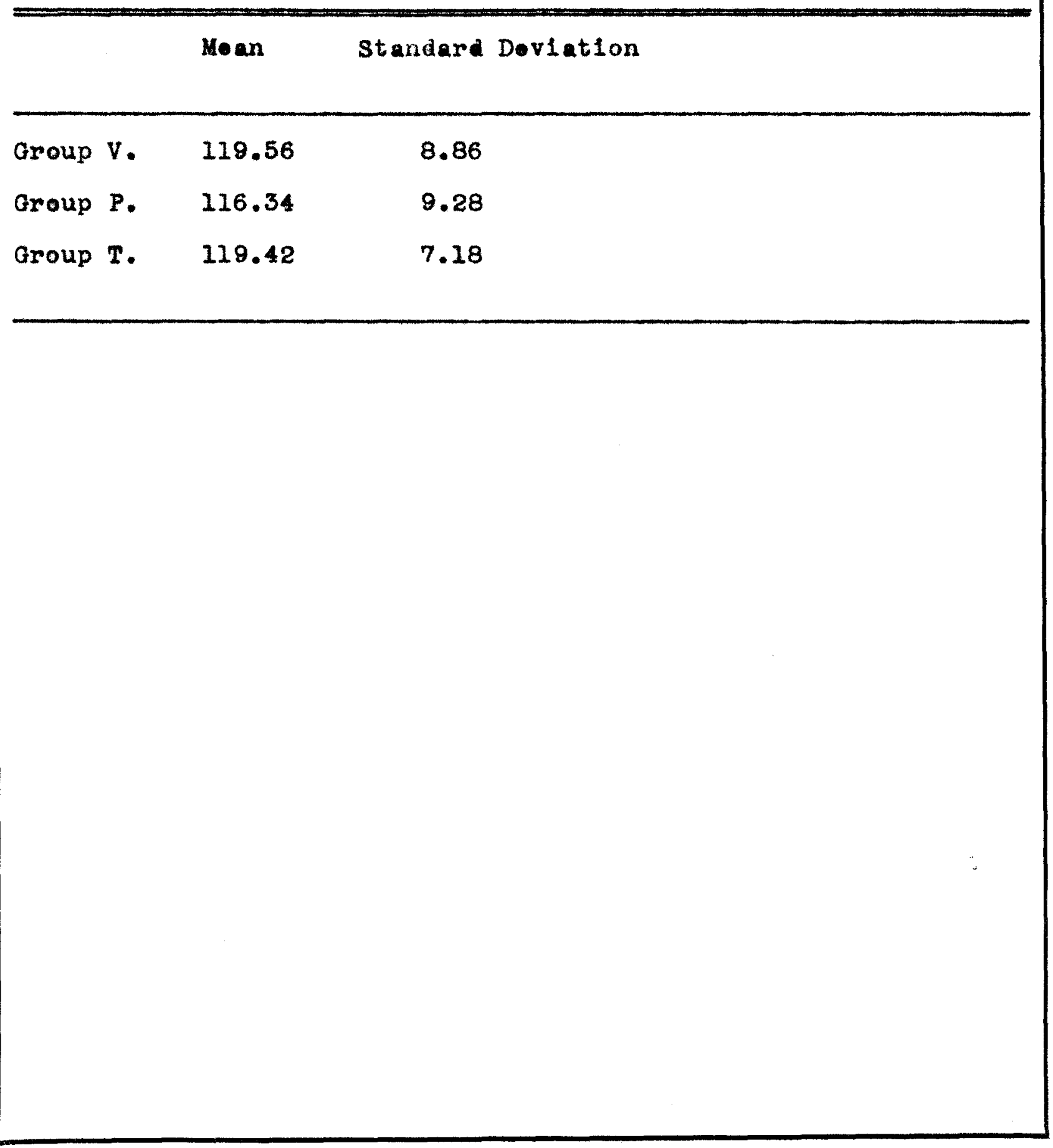


$-32-$

TABLE 12

MEAN AND STANDARD DEVIATION OF I.Q.SCORES for 50 MALES \& 50 FEMALES

Mean Standard Deviation

Group V. $\quad 120.83 \quad 9.46$

Group P. $\quad 115.79 \quad 10.47$

Group T. $\quad 118.78 \quad 7.57$ 


\section{TABLE 13}

MEAN AND STANDARD DEVIATION OF SCALED SCORF for 30 FEUALES

Moan Standard Doviation

Vocabulary \#

13.46

1.60

Arithmotic

11. 93

1.95

Block Dosign

11.33

3.00

Ploture Arrangement

11.56

2.47

Information

13.46

1.92

Similarities

13.03

2.00

Ploture Completion

11.76

1.69

D1git symbol

13.00

2.43

* Vocabulary, Arithmotic, Block Design, and Ploturo Arrangement were in the GROUP condition with Information, Similaritios, P1cturo Complotion, and Digit Symbol in the INDIVIDUAL

administration.

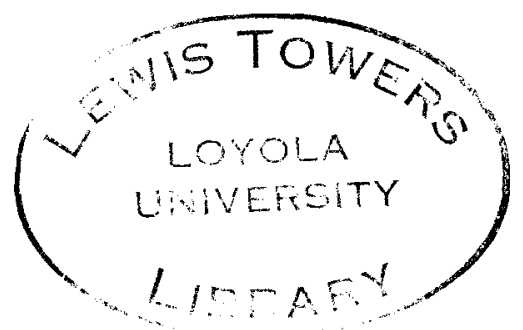




\section{TABIE 14}

UEAH AND STANDARD DEVIATION OF SCALED SCORE FOr 30 MALES

Moan Standard Deviation

Vecabulary

13.83

1.42

Arithmotic

18.36

2.29

Block Design

11.83

2.57

Ploture Arrangenent

11.26

1.93

Information

14.50

1.77

similaritio

12.33

1.80

Ploture Completion

11.93

2.00

Digit symbol

12.66

2.68 


\section{TABLE 15}

MEAN AND STANDARD DEVIATION OF SCALED SCORE fer 30 MALES 30

\section{Moan Standard Doviation}

Voobulary

Arl thmet 10

Block Design

Ploture Arrangenent

Information

Sinilaritios

Pleture Completion

Digit symbol
13.64

12.14

11.58

11.41

13.98

12.68

13.84

12.83
1.51

2.12

2.78

2.20

1.84

1.95

1.84

8. 55 


\section{TABLE 16}

MEAN AND STANDARD DEVIATION OF SCALED SCORE for 50 MALES

Mean Stariard Deviation

$\begin{array}{lll}\text { Information } & 14.68 & 1.70 \\ \text { Similaritios } & 12.88 & 1.00 \\ \text { Ploture Completion } & 12.14 & 1.00 \\ \text { DLgit Symbol } & 13.12 & 2.18\end{array}$


$-37-$

TABLE 17

MEAN AND STAUDARD DEVIATION OF SCALED SCORE for 50 FEMALES

\begin{tabular}{lll}
\hline & Moan & Standard Deviation \\
\hline Information & 13.22 & 2.00 \\
Similarities & 12.82 & 1.85 \\
pleture Completion & 11.76 & 1.81 \\
Digit Symbol & 13.00 & 2.14 \\
\hline & \\
\hline
\end{tabular}


$-38-$

TABLE 18

MEAN AND STANDARD DEVIATION OF SCALED SCORE fOr 50 MALES and 50 FEMALES

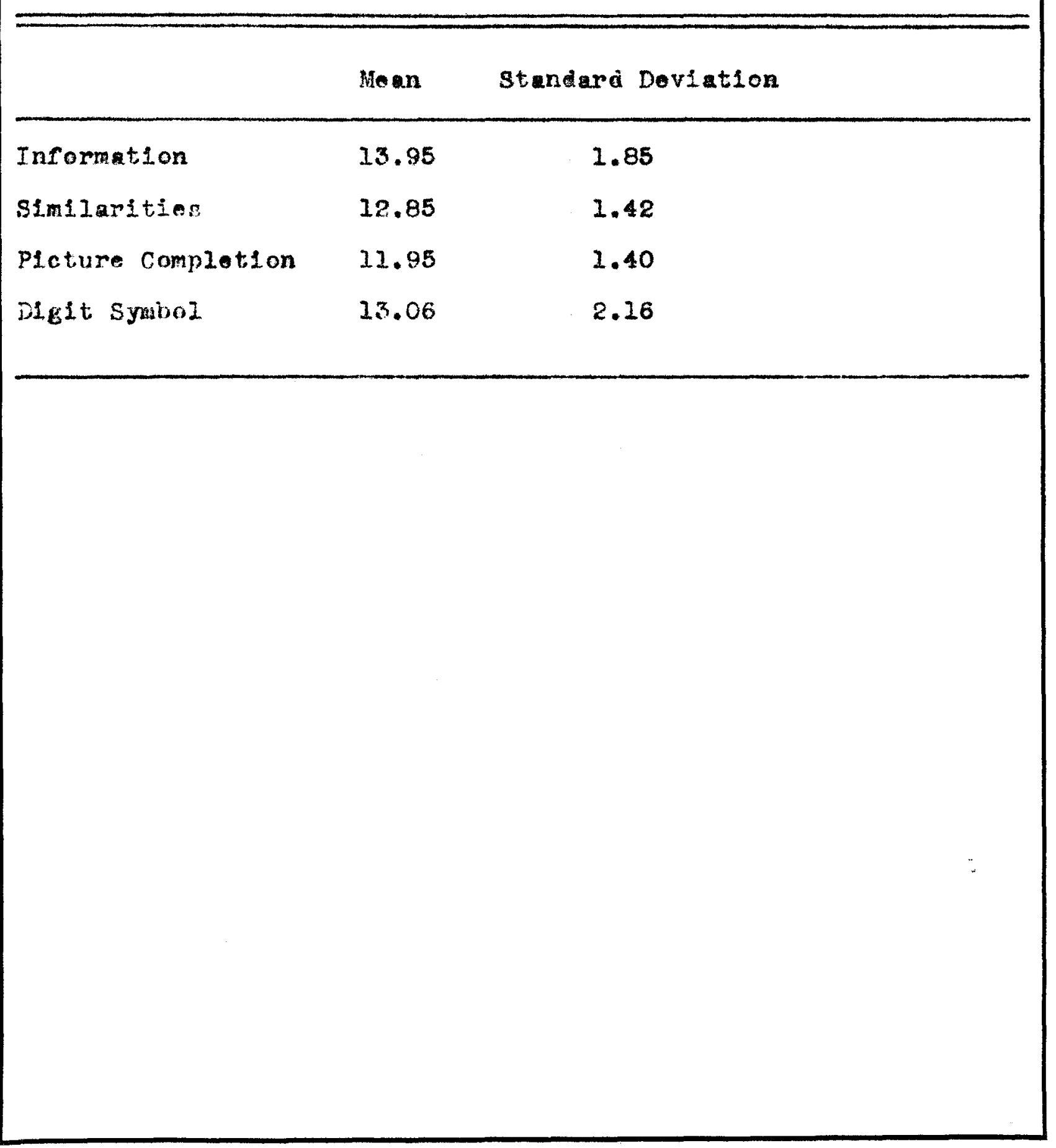




\section{$-39-$}

TABLE 19

PREDICTIOU OF IHDIVIDUAL I.Q. FROM GROUP I.Q.-30 MALES

$$
\text { Group I.Q. }
$$

Prodictod

Ind1v1dual I. Q.
Actual Ind1vidual I.Q.

\begin{tabular}{rrrr}
\hline 1 & 113 & 110 & 114 \\
2 & 118 & 115 & 104 \\
3 & 107 & 103 & 122 \\
4 & 114 & 111 & 92 \\
5 & 119 & 116 & 116 \\
6 & 114 & 111 & 118 \\
7 & 106 & 108 & 103 \\
8 & 109 & 105 & 114 \\
9 & 119 & 116 & 123 \\
10 & 128 & 125 & 122 \\
11 & 118 & 115 & 106 \\
12 & 128 & 125 & 128 \\
13 & 131 & 128 & 132 \\
14 & 116 & 113 & 110 \\
15 & 112 & 108 & 115 \\
16 & 127 & 124 & 111 \\
17 & 134 & 131 & 111 \\
18 & 126 & 123 & 125 \\
19 & 123 & 120 & 129 \\
20 & 120 & 117 & 109 \\
21 & 132 & 129 & 129 \\
22 & 126 & 123 & 130 \\
23 & 119 & 116 & 119 \\
24 & 119 & 116 & 128 \\
25 & 135 & 130 & 104 \\
26 & 119 & 116 & 114 \\
27 & 117 & 114 & 118 \\
28 & 124 & 122 & 132 \\
29 & 112 & 108 & 115 \\
30 & 127 & 124 & 115 \\
& & &
\end{tabular}




\section{TABLE 20}

PREDICTION OF INDIVIDUAI I.Q. FROA GROUP I.Q. - 30 PIWALES

Group I.Q.

Prodleted Indiv1dur]. I.Q.
Ac tual

Individual I.Q.

\begin{tabular}{|c|c|c|c|}
\hline $\begin{array}{r}1 \\
2 \\
3 \\
4 \\
5 \\
6 \\
7 \\
8 \\
9 \\
10 \\
11 \\
12 \\
13 \\
14 \\
15 \\
16 \\
17 \\
18 \\
19 \\
20 \\
21 \\
22 \\
23 \\
24 \\
25 \\
26 \\
27 \\
28 \\
29 \\
30\end{array}$ & $\begin{array}{l}112 \\
126 \\
121 \\
110 \\
122 \\
119 \\
126 \\
116 \\
131 \\
116 \\
113 \\
121 \\
108 \\
120 \\
118 \\
127 \\
127 \\
123 \\
126 \\
105 \\
119 \\
126 \\
138 \\
117 \\
123 \\
125 \\
133 \\
113 \\
114 \\
126\end{array}$ & $\begin{array}{l}106 \\
122 \\
116 \\
104 \\
118 \\
114 \\
122 \\
111 \\
128 \\
110 \\
107 \\
116 \\
101 \\
115 \\
114 \\
123 \\
123 \\
119 \\
122 \\
98 \\
114 \\
122 \\
136 \\
112 \\
119 \\
121 \\
130 \\
107 \\
108 \\
121\end{array}$ & $\begin{array}{r}118 \\
119 \\
114 \\
120 \\
118 \\
110 \\
120 \\
120 \\
112 \\
120 \\
106 \\
115 \\
96 \\
110 \\
115 \\
122 \\
120 \\
119 \\
125 \\
99 \\
120 \\
131 \\
141 \\
110 \\
129 \\
112 \\
126 \\
113 \\
103 \\
118\end{array}$ \\
\hline
\end{tabular}




\section{TABLE 21}

REORESSION EQUATIONS

Rogression Equation Standard Error of Bstimato

$\begin{array}{llll}\text { biale } & 1.04(-8) & 5.89 \\ \text { Female } & 1.26 & (-24) & 1.58\end{array}$


TALIE 22

DIFFERENCE IN MEAN I.Q. SCORES

\section{MALE}

30 FEMALE

Oroup I.Q. - Individuel I.Q. Group I.Q. - Ind1 VIdual I.Q.

$\begin{array}{rrrrr}1 & 120.03 & 117.00 & 120.70 & 116.23 \\ \mathrm{SD} & 7.50 & 9.73 & 7.63 & 9.23\end{array}$

th $-.52=1.65$

a $a \mathrm{f}^{\prime}=28$

p. .05 
PABLE 23

DIFFEREHCE IN MEAN I.Q. SCORES

30 MALE

Prodloted I.Q. - Aotual I.Q.
30 FBMALE

Prodicted I.Q. - Actual I.Q.

$\begin{array}{rrrrr}M & 117.23 & 117.00 & 126.23 & 115.63 \\ \text { SD } & 8.13 & 9.73 & 9.10 & 9.23\end{array}$

En

.55

.23

- $d r=28$

$p 4.10$ 


\section{TABLE 24}

\section{DIFFERENCE IN CORRELATED VARIANCE}

30 MALES and 30 PEMALES

\section{STANDARD DEVIATIOE}

Group Verbal

Individual Vorical

$t=.47 *$

Group Performance

Individual Porformance

$t=1.73$

Group Total

Individuel Total

$t=2.544444$
3.13

8.73

8.18

12.48

7.56

0.48

\section{$d r=28$}

4.01

4 \% 4.05

$4 * 40<05$ 
The reaults showed the corrected correlation botween group and Individual total I.Q. for malos and fomalos to bo high, ylelding correlations of .80 and .96 rospectively. When male and femalo Ss wore combined, the resulting corrected correlation botwoen individual and group total I.Q. was equally high, boing .88. Hence the high corrolations suggest the apparent comparab1I1ty in scores obtained under the two types of test administration.

ThIs comparablilty is furthor supported by the results of the $t$ tests which showod that thare was no signifloant difforonce botwoen the individual and group moan total I.Q.'s for both males and fomales.

This comparability recolvos still further support from the accuracy of the predictions made on the basis of the group administration in which the $t$ tosts showed that there was no significant difference botweon the moan predictod I.Q. and the mean actual I.Q. for both malos and fomales.

In sum the apparent comparability of scores obtalnod under the two typos of tost adminlstration point to the fossibility of the use of the WaIS as a group test of Intelligenee.

For the most part the results corresponded to what would be expected on the basis of Weschlor's norms and the characteristios of the ample Itsolf. Verbal I.Q. execeded Performance I.Q. In 
both adminfitrations and for both sexes. The sex difforenees followed the usual patterning with the males proving superior to the fomales on the subteats of Arlthmetle, Block Design, Information, and Pleture Completion and the fomales proving superior on the subtests of Plcture Arrangemont, similarities, and D1git Symbol. The one discrepancy was on the subtest of Vocabulary in whioh the lele unexpectedly proved superior to the romales. The resson for thl way be that wheroas all the wale se were full time college undergraduates, olose to $1 / 4$ of the fomale sg nore only part-time college undergraduates. Hence it might be oxpected that the males would perform better on Vocabulary than the fomales sirce this subtest in comparison to the other subtests employed would be more soneltive to the superior rerbal akili a full time atudent might be expected to have as compared with a part-t1mo student. Th1 was borne out by chockIng the moen vocabulary seore for the part-time gtudents; and it was found to be a full soaled woore point below that of the moan for the full-time fomale $\mathrm{S}$ In the sample.

The above average I.Q. of the Ss whioh ran roughly to a IIttle over one standard deviation from the moan corresponds to what would bo expected from a colloge population. Also the deoreased rariablitty found in the seores is to be expected in viow of the homogenelty of the $8 \mathrm{a}$ wo comprised the sample.

The intercorrelation among the tests is also oongruent with what would be expected in view of Wosoblor's norms exeopt for the Group Porformance scores whose cerrelation wore conalatentiy lower 


\section{$-47-$}

than what would bo expected.

The above flnding have implications more for the use of the group waIs as a rosearch tool rather ther a olinical tool bocauae a group WAIS Foula involve the loss of qualitative observation and the discropancios in Indvidual subtest performance, its value as a clinical tool would be mintmal unless all the clinician wanted was a staple I.Q. Theri used in this way or us a screening dovioo, It would soom that a Eroup WAIS would be suporior to many of the tasts now omployed 1n these functions because of the quickness with which it can bo administered (the group administration in the present study took $1 / 2$ hour), the age ranges it covers, ani its superior validity and roliability.

Its chief value huwever would be as a research tool for the studylng of intolizgaroo por so or as one of a host of variables. For the rosults of this study suggeat that the researcher oan place as high a confidonoe and surety in a group WaIs as ho prosently doos in an Individually admlnistorod WAIS. Hence a researcher intorestod in studying $I . Q$. as variablo or merely wishing to oquato groups in torms of thia variablo is onablod to do so in shortor time, than he normally would. Ho is also able to study a much broader population with much more confidence then he norrally would have booauge of the exeellenee of the WAIS' norms. And finaliy he oan bo assured that the I.Q. ho derives from the use of the group WaIs $1 \mathrm{~s}$ a valid one. For these reasons it would soom that a group WAIS would be an oxcelient Instrument to be aded to the researcher'g arwamentarium. 


\section{Summery}

One hundrod $\underline{\text { s }}$, fifty male and fifty fomale woro teated by the same $E$ on group WAIS - I, S, PC, DS - and sixty of those one hundred SS, thirty malo and thirty fomalo, woro testod by the sane $\underline{E}$ on an indiviual VAIS -- V, $A, B D$, and $P A$. It was hypothesizod that the scoros obtained in the group adrinlstration would bo oomparable to those obtalned in an individual aministration.

The hypothosis was supportod and implications for the uso of a group WAIS as a research instrument were disoussed. 
Anastas. Anne, Peychological Tosting, N.Y.s Mac 1iian, 1954, P. 348.

Eell, A., and Zubek, J. The effeot of age cn the intollecturl performance of mental defectives. Journal of Garontology, 1960, 15, 285-285.

Eradway, K.P., and Thompson, C.W. Intell1gence et edulthood, A twenty year follow-up. Journal of Educational Payohology. 1862. 53. $2-14$.

Crites, J., Cited in Buros, 0.K. The Sixth Montal Messurements Yourbook, The Gryphon Press, HIghIand Park, N.J., 1865, P.462.

Cronbach, Loe J. Essentials of Psrohologloal Testing, N.Y., Harper, 1960, p.217.

Darbes, A. Relationships amone coliege stuant scores on ACF, Ot1s and HAIS tests, Proceodings of the West Vireinia Aoademy of Sclence, $1960,32,214-216$.

De Iuca, J.N. Counitive task performance in schlzophrenfa 28 a function of promorble history, ereluation, and sot to improve. Dissertation Abstruots, 1964, 24, 3834-3835. (Abatract)

Doppelt, J. Eatimating the Full Scalo score on the Wosehler Bellevue Adult Intelligence Scale from scores on 4 subtests. J. consult. Psychol., 1956, 20, 63-66.

Esiajorer, C, the WAIS performance of the aged: A retest - valuation. Journal of CerontologJ, 1863, 18, 169-172.

Fargo, G., Orowell D., Noyes, M., Fuchlgami, R., Gordon, J., Dunn-Rankin, P., Comparability of group tolovision and individual Adrinistration of the Poabody Plcture Vocabulary Teat, Journal of Education Paychology, 1967, 58, pp. 137-140.

Preoman, Frank J.: Citod in Buros, 0.K. The Flfth Mental Mezsuremonts Yoarbook. The Gryphon Press, Highland Park, N. J., 1959, P. 314.

Gilgesh, C. A. Thorazine therapy with catatonic schizophrenics in relation to Weschler Vorbal and Porformance subtest comparison. Journal of Clinical Psychology, 1961, 17, 95.

Guertin, W. H.: Citod in Buros, 0.K. The Fifth Montal Moasuremont Yoarbook. The Gryphon Pros8, Highland Park, 1959, P.415. 
Guortin, Wilson H., Ladi, Clayton E., Frank, Goorg H., Rabla, Albert I., Holster, Douglas, S., Researeh with the Weschlor Intelligonoe Scalo for Adulta: 1960-1965, Psyeh. Bull., 66, pp. 385-409.

Hall, Jullan C., Correlatior of a modifled form of Raven's Progressive Matrices (1938) with the WAIS J. consult. Psychol., 1957, 21, pp. 232-236.

Harrower, N. Psjchodlagnost1c tosting: An Emplrical approach., Springfield, Ill.: Charles C. Thomas, 1965.

Hiskoy, Marshall, C1to in Buros, 0.K. The S1xth Mental Measurements Yearbook. The Gryphon Pross, Highland Park, W.J. 1965, p. 517 .

Hoyt, Cyril J.: Citod in Buros, 0.K. The Fifth Mental Measurements Yoarbook, The Gryphon Press, Highland Park N.J., 1959, P.359.

Hullcka, I.A. Vorbal WAIS seoros of eldorly pationts, Psychologleal Reports, 1962, 10, p.250.

Ives, Margaret,: Cited in Buros, O.K. The Third Mental Measurements Yearbook, Rutgers University Press, New Brunswick, N.L., 1949, p. 95.

Jurjovioh, R., An evaluation of the Henmon-Neleon group I.Q. test with delinquent girls. Journal of General Pgychology, 1963.

68, pp. $227-233$.

Koats, J.: Cited In Buros, 0.K. The Sixth Montal Heasurements Yearbook, The Gryphon Press, H1ghland Park, H.J., 1965, p.767.

Lefovor, Wolty, D.: Cited in Buros, O.K. The Sixth Mental Measuredents Yoarbook, The Gryphon Press, H1ghland Park, K.J.,1865, P.480.

tevino, M., Spivak, G., and Wright, B. The inhibition process, Rorschech human movoment reaponses, and intelligonce. Somo fur ther data. Journal of Coneultirg Paycholocs. 1858, 23, pp. 306-312.

Laxwoll, E. Validities of abbroviated WAIS scalos. J. consulting sychol. 1957, 21, pp.121-126.

Cluood, H.N., Rabin, J. Correlation betwoon Ravens Progreselve latrloes and the WAIs. Journel of consult. Psychol., 1962, 26, p. 190-191.

ewland, T.: Cltod in Buros, 0.K. The S1xth Montal Measurements foarbook. The Gryphon Press, N.J., 1865, P. 517. 
Orne, J.E. The colored Progressive Matrices as a measure of Intolloctual subnormality. British Journal of Modical Payoholory. $1961,34, \mathrm{pp} .291-297$.

Pldgeon, Douglas A.: Cltod in Buros, 0.K. The Sixth Montal Moesuroments Yoarbook. The Gryphon Pross, HighIand Park, N.J., $1965, \mathrm{p} .466$.

Shaffor, R.: Cited in Buros, 0.K. The Flfth Montal Moasuroments Yoarbook, The Gryphon Pross, Highland Park, N.J., I859, P.343.

Silverstoin, A.B. Longth of hospltalization and intelifigene tost porformance in montalis rotarded adults. Amorican Journal of Mental Deflcloney, 1862, 66, pp.618-620.

Stone, L.A., Ramor, J.C. Estimating WAIS I.W. from Sh1ploy Scale score: Another cross-validation. Journal of elinical Psrchology, $1965,21, \mathrm{p} .297$.

Sulnn, R.M. The Shlpley-Hartford Retroat Scalo a a acoening tost of Intelligence. Journal of Clinioal Psqohology, 1960, 16, p.429.

Tarjan, G., Dingman, H.F., Ejman, R.K., and Brown, S.J. Effectiveness of hospltal rolease program. Amerlean Journal of Mental Deflclency, 1960, 61, pp. 609-617.

Tyler, T.: C1tod in Buros, 0.K., The Fifth Montal Mousurements Yearbook, The Gryphon Prose, HIghIand Park, 1959, P. 343.

Wahler, J.J., Watson, I.S. A comparison of the Shipley-Hartford as a power test with the fiIs Vorbal Sealo. Journal of consult. Psychol., 1962, 26, p. 105.

Walker, R.E., Hunt, W.A. and Sohwartz, M.L. Tho difficulty of WAIS comprehonsion scoring. Joumnal of Clinical Psyeholory. 1965,21 , pp. 427-429.

Wallen, Noman E.: Cltod in Buros, 0.K. The S1xth Montal Moagurements Yearbook. The Gryphon Press, Highlend Park, H.J.. 1965, p.462.

Warron, S.A., Coilier, J.L. Suitablilty of the Columbia Montal Maturity seale for mentally retardod institutionalized fomalos, Americain Journal of Montal Defloloney, 1960, 64, pp. 916-920.

Woschlar, D. The Willians and Wilkin Co., Baltimore, Md." 1959. 
Wions, A.N., Banaka, N.J. Est1mating WAIS I.Q. Prom ShiployHartford scores: A cross-valietion. Journal of Clinical Paychology, 1960,16, p. 432 . 


\section{APPROVAL SHEET}

The thesis submitted by Robert Francis Eme has been read and approved by the director of the thesis. Furthermore, the final coples have been examined by the director and the signature which appears below verifies the fact that any necessary changes have been incorporated, and that the thesis is now glven finel approvel with raforence to content and form.

The thesis is therefore accepted in partial fulfullment of the requirements for the degree of Master of Arts.

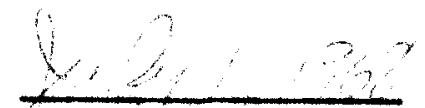

Date

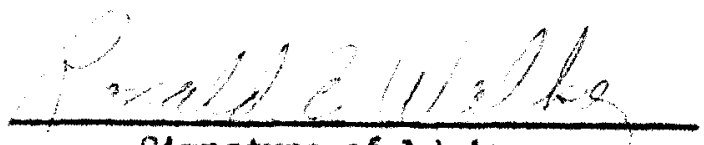

Signature of Adviser 